\title{
Behçet Hastalarında Metilglioksal, İskemi Modifiye Albumin Düzeyleri ve Prolidaz Aktivitesinin Araştırılması
}

\section{Investigation of Methylglioxal, Ischemia-Modified Albumin Levels and Prolidase Activity in Behcet's Patients}

\author{
Duygu ERYAVUZ ONMAZ $^{1}{ }^{(D)}$, Abdullah SIVRIKAYA $1{ }^{1}(\mathbb{D})$, Sedat ABUŞOĞLU 1 (D), Sema YILMAZ 2 (D), \\ Gülsüm ABUŞOĞLU ${ }^{3}$ (D) , Lütfiye TUTKUN 4 (D), Ali ÜNLÜ 1
}

\begin{abstract}
1 Selçuk Üniversitesi Tıp Fakültesi, Biyokimya Anabilim Dalı, KONYA
2 Selçuk Üniversitesi Tıp Fakültesi, Romatoloji Anabilim Dalı, KONYA

3 Selçuk Üniversitesi Sağılk Hizmetleri Meslek Yüksekokulu, Tıbbi Laboratuar Teknikleri Anabilim Dalı, KONYA

4 Yozgat Bozok Üniversitesi Tıp Fakültesi, Biyokimya Anabilim Dalı, YOZGAT
\end{abstract}

Öz.

Amaç: Behçet hastalığı otoimmün, kronik, enflamatuvar, multisistemik bir hastalıktır. Hastalıkta yaygın olarak oral aft, genital ülserler, cilt lezyonları, üveit görülmekle birlikte temel patolojik bulgu vaskülittir. Behçet hastalığının spesifik bir laboratuvar bulgusu yoktur. Behçet hastaliğında eritrosit sedimentasyon hızı, C-reaktif protein gibi çeşitli rutin parametrelerin düzeylerinde yükseklikler belirtilmekle birlikte bu parametrelerin düzeylerindeki değişiklikler klinik aktiviteyle her zaman paralellik göstermemektedir. Bizim bu çalışmadaki amacımız Behçet hastalı̆̆ ile iskemi modifiye albumin, metilglioksal ve serum prolidaz aktivitesi arasındaki ilişkiyi ortaya koymaktır.

Materyal ve metod: Callşmaya 35 Behçet hastası, 35 kontrol dahil edilmiștir. Tüm bireylerin metilglioksal düzeyleri kromatografik yöntemle Thermo Ultimate 3000 Ultra-Yüksek Performanslı Likit Kromatografisi cihazında, serum iskemi modifiye albumin düzeyleri ve prolidaz aktivitesi spektrofotometrik (Perkin Elmer Lambda 25 UV/Vis, US ) yöntemle ölçülmüștür.

Bulgular: Behçet grubunda serum iskemi modifiye albumin $(p<0.001)$, prolidaz, metilglioksal $(p<0.001)$, nötrofil lenfosit oranı $(p=0.011)$, platelet lenfosit oranı $(0.015)$, eritrosit sedimentasyon hızı $(p=0.047)$, eritrosit dağılım genişliği $(p=0.021)$, nötrofil( $\mathrm{p}=0.007)$ düzeyleri kontrol grubuna göre istatistiksel olarak belirgin düzeyde yüksek bulunurken, ortalama eritrosit hemoglobin konsantrasyonu değeri ise kontrol grubuna göre istatistiksel olarak belirgin düzeyde düşük bulunmuştur $(p=0.010)$. Sonuç: Serum iskemi modifiye albumin, metilglioksal düzeyleri ve prolidaz aktivitesi Behçet grubunda kontrol grubuna göre istatistiksel olarak belirgin düzeyde farklı bulunmuştur.

Anahtar kelimeler: Behçet Hastalığı, Metilglioksal, Prolidaz, Vaskülit

Abstract

Background: Behçet's disease is an autoimmune, chronic, inflammatory, multisystemic disease. Although oral aphthae, genital ulcers, skin lesions and uveitis are commonly seen in the disease, vasculitis is the main pathological finding. There is no laboratory finding specific to Behçet's disease. The levels of various routine parameters such as erythrocyte sedimentation rate and C-reactive protein have been shown to be high in Behçet's disease, however, the change in these parameters is not always consistent with clinical activity. The aim of this study was to investigate the relationship between Behçet's disease and ischemiamodified albumin, methylglyoxal and serum prolidase activity.

Materials and Methods: 35 Behçet patients and 35 controls were included in to the study. Serum ischemia-modified albumin levels and prolidase activity were measured spectrophotometrically (Perkin Elmer Lambda 25 UVNVis, US) and serum methylglyoxal levels were measured by Thermo Ultimate 3000 Ultra-High Performance Liquid Chromatography.

Results: In the Behcet group, serum ischemia-modified albumin $(p<0.001)$, prolidase, methylglyoxal $(p<0.001)$, neutrophil lymphocyte ratio $(p=0.011)$, platelet lymphocyte ratio $(0.015)$, erythrocyte sedimentation rate $(p=0.047)$, erythrocyte distribution width $(p=0.021)$, neutrophil $(p=0.007$ ) levels were found to be significantly higher than the control group, whereas mean corpuscular hemoglobin concentration value was found to be significantly lower than the control group $(p=0010)$.

Conclusions: Serum ischemia modified albumin, methylglioxal levels and prolidase activity were statistically significantly different in the Behçet group compared to the control group.

Keywords: Behçet's disease, Methylglioxal, Prolidase, Vasculitis

\section{Sorumlu Yazar I \\ Corresponding Author}

Duygu ERYAVUZ ONMAZ

Selçuk Üniversitesi Tıp Fakültesi Biyokimya ABD

Alaaddin Keykubat Kampüsü, 42075 Selçuklu, Konya

\section{Tlf: 033244781}

e-mail: duygu_eryavuz@hotmail.com

Geliş tarihi / Received:

09.01.2020

Kabul tarihi / Accepted: 04.06.2020

DOI: 10.35440/hutfd. 672393 


\section{Giriş}

1937 ylında Türk dermatolojist Hulusi Behçet tarafından tanımlanan Behçet hastalığı; nadir görülen, kronik, rekürren, enflamatuvar bir hastalık olup birçok organda tutulum göstermektedir (1). Behçet hastalığı, tarihi İpek Yolu üzerinde yer alan Çin, Türkiye, İran gibi ülkelerde (1420/100.000 nüfus) oldukça yaygın olarak görülen bir hastalıktır. Hastalık en yaygın olarak Türkiye'de görülmekte olup (80-370/100.000 nüfus), batıda insidansı daha düşüktür (Birleşik Krallık'ta 0.64/100.000 nüfus ve Amerika Birleşik Devletleri'nde 0.12-0.33/100.000 nüfus) (2). Behçet hastalığı özellikle 20-40 yaş arası bireylerde yaygın olarak görülmekte olup kadın ve erkeklerde görülme sıklığı eşittir. Behçet hastalığında genetik faktörlerin önemli rol oynadığını gösteren çok sayıda kanıt bulunmakta olup, en güçlü genetik yatkınlık faktörü HLA-B51 genidir. HLA-B51 geni behçet hastalarının yaklaşık olarak \%60'ında pozitiftir (3). Behçet hastalığının etiyopatogenezi henüz tam olarak aydınlatılamamıştır, ancak hastalı̆ın patogenezinde genetik etmenlerin yanı sıra, viral ve bakteriyel enfeksiyonların, humoral ve/veya hücresel bağışıklıktaki kusurları içeren bir dizi faktörün rol oynadığı düşünülmektedir (4). Hastalığa spesifik tanısal laboratuvar testleri veya histopatolojik bulgular olmadığından hastalığın tanısı klinik kriterlere dayalı olup, kesin tanının konması genellikle ilk belirtilerin ortaya çıkmasından sonra birkaç yılı bulmaktadır. Bununla birlikte Behçet hastalığının bulguları tutarlı değildir, klinik fenotipler oldukça heterojendir ve hastalığın prognozu etnik, coğrafi ve bireysel farklııklara bağlı olarak değişmektedir (5). Bu durumda, Behçet hastalığının tanısında yeni, spesifik biyobelirteçlere olan gereksinimi artırmaktadır. Behçet hastalı̆̆ı, oküler, kardiyovasküler, gastrointestinal, renal, pulmoner, ürolojik, nörolojik sistem ve eklemler dahil olmak üzere hemen her sistemi ve organı etkileyebilmektedir (6). Bununla birlikte Behçet hastalığında ana patolojik proses çeşitli büyüklükteki damarları etkileyen vaskülit ve perivasküler infiltrasyondur. Behçet hastalığında vasküler sistem tululumu \%25-30 oranında görülmekte olup en önemli mortalite nedenidir (7). Hastalıkta meydana gelen vasküler tutulumun altında yatan mekanizmalar henüz tam olarak aydınlatılamamış olmakla birlikte, vasküler tutulum primer olarak damar duvalarındaki oto-enflamasyonla karakterize olup, immunoregülatörsistemdeki değişikliklerin ve oksidatif stresin vasküler hasar ile ilişkili olabileceği düşünülmektedir $(8,9)$.

Metilglioksal (MG) oldukça reaktif, sitotoksik bir alfa-oksoaldehit bileşiği olup endojen olarak çeşitli enzimatik yada non-enzimatik reaksiyonlarla üretilmektedir (10). MG, protein ve yağ asidi metabolizmasının bir yan ürünü olarak üretilebilse de glikolitik yol ile triozfosfatların degredasyonu, MG üretiminin en önemli endojen kaynağıdır (11). MG güçlü bir protein-glikasyon ajanı olup ileri glikasyon son ürünleri (AGEs) için önemli bir prekürsördür (12). Ya- pılan çalışmalarda AGEs ve MG düzeylerinin diyabet, ateroskleroz, obezite, multiple skleroz, romatoid artrit gibi birçok enflamatuvar hastalıkta yükseldiği gösterilmiştir (13). Ayrıca MG'nin vasküler hasarla ilişkili olduğuna dair önemli bilimsel kanıtlar olmasına rağmen, henüz aralarındaki ilişkiyi açıklayan patolojik mekanizmalar tam olarak aydınlatılamamıştır (14).

Prolidaz hayvan ve insan dokularında bulunan bir enzim olup kollajen sentezi ve yıkımında önemli rol oynamaktadır. Serum prolidaz aktivitesi (SPA) fibrotik hastalıklar, kronik yaralanmalarda değişmekte olup oksidatif stresten etkilenmektedir. Yapılan çalışmalarda prolidazın büyüme ve transkripsiyon faktörlerinin (Vascular Endothelial Growth Factor (VEGF) ve Hypoxia-Inducible Factor-1a (HIF-1a)) ekspresyonu vasıtasıyla yara iyileşmesi, enflamasyon, anjiogenez gibi çeşitli fizyolojik ve patolojik proseslerde önemli rol oynayabileceği gösterilmiştir. VEGF, Behçet patolojisinde de rol oynayan mekanizmalar olan anjiogenez ve enflamatuvar süreçte önemli bir faktördür. Dolayısıyla prolidaz aktivitesinin, VEGF aracılı etkileri nedeniyle behçet patogeneziyle ilişkili olabileceği düşünülmektedir (15). Serum albumininin N-terminal ucunda kobalt, bakır, nikel gibi geçiş metalleri için bağlanma bölgesi bulunmaktadır. İskemi modifiye albumin (IMA), oksidatif stres, iskemi gibi durumlarda albuminin N-terminal ucunun geçiş metallerini bağlama kapasitesinin azalmasıyla oluşmaktadır (16). IMA, FDA tarafından şüpheli miyokard iskemisinin tanısı için onaylanmış oldukça sensitif bir biyobelirteçtir. Bununla birlikte romatoid artrit, psöriyazis, enflamatuvar bağırsak hastalığı gibi çeşitli enflamatuvar hastalıklarda, oksidatif stresle ilişkili bozukluklarda da IMA düzeylerinin yükseldiği bildirilmiştir (17-20).

Bizde çalışmamızda, Behçet hastaları ile sağlıklı bireylerde MG, IMA ve prolidaz düzeylerini ölçerek bu markırların hastalık tanısındaki potansiyel rolünü aydınlatmayı amaçladık.

\section{Materyal ve Metod \\ Hastalar}

Bu çalışma Eylül 2019-Aralık 2019 tarihleri arasında Selçuk Üniversitesi Tıp Fakültesi Hastanesinde yapılmışı̧ır. Çalışmaya hastanemiz Romatoloji polikliniğine başvuran 35 Behçet hastası ile herhangi bir kronik rahatsızığı bulunmayıp, rutin kontrol amaçlı hastanemiz Aile hekimliği polikliniğine başvuran 35 sağ lıklı kontrol dahil edilmiştir. Çalışmamız Selçuk Üniversitesi Tıp Fakültesi Yerel Etik Kurul Başkanlığının 18/09/2019 tarih ve 2019/217 sayılı etik kurul kararıyla onaylanmıştır. Etik kurul onayını takiben çalışmaya dahil edilen bireylerden jelli ve EDTA'lı tüplere kan örnekleri alınmıştır. Hastalardan alınan jelli tüpten elde edilen serum örneklerinde üre, kreatinin ve alanin aminotransferaz (ALT) düzeyleri Beckman-Coulter AU 5800 (Beckman Coulter, Brea, USA) cihazında ölçülmüştür. Kalan se- 
rum örneklerinde ise IMA ve SPA spektrofotometrik yöntemle, MG düzeyleri ise kromatografik yöntemle ölçülmüştür. Hastalara ait beyaz küre sayısı (WBC), hemoglobin (HGB), hematokrit (HCT), platelet (PLT), kırmızı kan hücre sayısı (RBC), ortalama eritrosit hacmi (MCV), ortalama korpusküler hemoglobin (MCH), eritrosit dağılım genişliği (RDW), trombosit dağılım genişliği (PDW), ortalama platelet hacmi (MPV), nötrofil (NEU), lenfosit sayısı (LYM), ortalama eritrosit hemoglobin konsantrasyonu ( $\mathrm{MCHC}$ ) değerleri, EDTA'lı tüpten elde edilen tam kan örneklerinde Beckman Coulter LH 780 analyzer (Beckman Coulter, Miami, FL, USA) cihazında ölçülmüştür. Nötrofil lenfosit (NLO) ve platelet lenfosit oranları (PLO) ise ölçüm sonuçlarından hareketle hesaplanmıştır. Eritrosit sedimentasyon hızı (ESR), Alifax (Padova, Italy) cihazında ölçülmüştür.

\section{Kimyasallar}

2-metilkinoksalin (2-MQ) (CAS Numarası 7251-61-8), 5metilkinoksalin (5-MQ) (CAS NumarasI: 13708-12-8), ortofenilendiamin (0-PD) (CAS NumarasI: 95-54-5), perklorik asit (PCA) (ACS reaktif derecesi) (CAS Numarası:760190-3), Tris $\mathrm{HCl}$ (CAS Numarası: 1185-53-1), L-Glutatyon (CAS Numarası 70-18-8), $\mathrm{MnCl}_{2}$ (CAS Numarası: 777301-5), L- Prolin-Glisin (CAS Numarası 2578-57-6), asetik asit (CAS Numarası: 64-19-7), sodyum hidroksit (CAS Numarası:1310-73-2), hidroklorik asit (CAS Numarası 764701-0), ninhidrin (CAS Numarası:485-47-2), 0- fosforik asit (CAS NumarasI: 7664-38-2), prolin (CAS Numarası: 14785-3), kobalt klorid (CAS NumarasI: 7646-79-9), dithiothreitol (DTT) (CAS NumarasI: 3483-12-3) , HPLC analizlerine uygun saflıkta asetonitril (CAS Numarası: 75-05-8), metanol (CAS Numarası: 67-56-1), su (CAS Numarası: 773218-5) Sigma-Aldrich'ten (St. Louis, MO, ABD) temin edilmiştir.

\section{Serum Metilglioksal Analizi}

MG düzeyleri Wang ve ark. tarafından geliştirilen yöntem modifiye edilerek Thermo Ultimate 3000 Ultra-Yüksek Performansı Likit Kromatografisi (UHPLC) cihazında ölçülmüştür (21). Kısaca; koyu renkli ependorflara $200 \mu \mathrm{L}$ numune, 200 mikrolitre internal standart olarak 5-metilkinoksalin (69 milimolar), çöktürücü olarak $100 \mu \mathrm{L}$ perklorik asit ve türevlendirici olarak da $250 \mu \mathrm{L}$ orto-fenilen diamin (100 milimolar) eklenerek 30 saniye vortekslenmiştir. Daha sonra numuneler karanlık ortamda, oda sıcaklığında 24 saat inkübasyona bırakılmıştır. Süre sonunda 15.000 rpm'de $\left(4^{\circ} \mathrm{C}\right.$ 'de ve 10 dakika) santrifüj edilerek süpernatan kısmından $200 \mu \mathrm{L}$ insert viallere alınmış ve UHPLC sistemine $20 \mu \mathrm{L}$ enjeksiyon yapılmışıır. MG düzeylerinin ölçümü ise MG türevi olan 2-metilkinoksalinin $315 \mathrm{~nm}$ dalga boyunda verdiği absorbanstan yararlanılarak gerçekleştirilmiştir. MG düzeyleri iç standart olarak kullanılan 5-metilkinoksaline karşı 2-metilkinoksalin pik alanı kullanılarak hesaplanmıştır. Kromatografik ayrım Phenomenex Luna C18 $(3 \mu \mathrm{m}, 4.6 \times 50 \mathrm{~mm})$ kolonu ve mobil faz olarak ise izokratik elüsyonla $1.2 \mathrm{~mL} / d a k$. akış hızında su:asetonitril çözeltisi
(4:1, \%v:v) kullanılarak sağlanmıştır. Total analiz süresi 10 dakika olup, kolon fırını sıcaklığı $35^{\circ} \mathrm{C}$ olarak ayarlanmıştir.

\section{Serum Prolidaz Aktivitesinin Ölçümü}

SPA, Myara ve ark. tarafından belirtilen yöntem modifiye edilerek ölçülmüştür (22). Kısaca, $100 \mu \mathrm{L}$ serum numunesine $100 \mu \mathrm{L}$ serum fizyolojik çözeltisi ilave edilerek vortekslendi. Bu karışımdan ayrı ependorflara $25 \mu \mathrm{L}$ alınarak üzerine $75 \mu \mathrm{L}$ ön inkübasyon karışımı (1 mmol/L glutatyon, 50 $\mathrm{mmol} / \mathrm{L} \mathrm{MnCl} 2$ içeren $50 \mathrm{mmol} / \mathrm{L}$ Tris $\mathrm{HC} 1 \mathrm{pH} 7.0$ tamponu) ilave edildi ve 30 dakika boyunca $37^{\circ} \mathrm{C}$ sıcaklıkta inkübe edildi. İnkübasyondan sonra, reaksiyon karışımına $100 \mu \mathrm{L} 144 \mathrm{mmol} / \mathrm{L}$ glisin-prolin (pH 7.8) çözeltisi ilave edildi, daha sonra $37^{\circ} \mathrm{C}$ 'de 5 dakika inkübe edildi. Süre sonunda inkübasyon reaksiyonunu sonlandırmak için $1 \mathrm{~mL}$ glasiyel asetik asit ilave edildi. Daha sonra $300 \mu \mathrm{L}$ Tris $\mathrm{HCl}$ tampon çözeltisi $(\mathrm{pH} 7.8)$ ve $1 \mathrm{~mL}$ ninhidrin reaktifi $(3 \mathrm{~g} / \mathrm{dL}$ ninhidrin, $0.5 \mathrm{~mol} / \mathrm{L}$ ortofosforik asit içerisinde çözüldü) ilave edilerek reaksiyon karışımı, $90^{\circ} \mathrm{C}$ ' de 25 dakika süreyle inkübe edildi ve süre sonunda hızla soğutuldu. Prolin seviyeleri numunelerin ve hazırlanan standartların $515 \mathrm{~nm}$ dalga boyundaki absorbans değerlerinden faydalanarak kalibrasyon grafiği yardımıyla spektrofotometre cihazında (Perkin Elmer Lambda 25 UV/Vis, US) ölçüldü.

\section{İskemi Modifiye Albumin Düzeylerinin Ölçümü}

IMA seviyeleri, Bar $O$ ve ark. tarafından belirtilen yönteme göre ölçülmüştür (23). Kısaca; $200 \mu \mathrm{L}$ serum örneğine 50 $\mu \mathrm{L} \% 0.1$ kobalt klorür ilave edildikten sonra reaksiyon karışımı, 10 saniye boyunca vortekslendi ve albumin-kobalt bağlanmasını sağlamak için 10 dakika süreyle oda sıcaklığında inkübe edildi. Daha sonra, $50 \mu \mathrm{L}$ Ditiyotreitol (DTT) $(1.5 \mathrm{mg} / \mathrm{mL})$ albumine bağlı olmayan kobalt ile kolorimetrik reaksiyonu sağlamak için reaksiyon karışımına ilave edildi ve 2 dakika boyunca oda sıcaklığında inkübe edildi. Inkübasyondan sonra reaksiyon karışımına, reaksiyonu durdurmak için $1 \mathrm{~mL}$ izotonik salin çözeltisi ilave edildi. Kör tüpü ise herbir serum örneği için aynı prosedürle DTT ileve edilmeden hazırlandı. Numuneler ve körlerin absorbans değerleri dalga boyu 470 nm'ye ayarlanmış spektrofotometre cihazında (Perkin Elmer Lambda 25 UVNis, US) ölçülerek aralarındaki spektrofotometrik ölçüm farkı serum IMA seviyeleri olarak ifade edildi.

\section{İstatiksel Analiz}

Sürekli değişkenlerin normal dağı̆lım gösterip göstermediği Kolmogorov-Smirnov testi ile analiz edilmiştir. Hasta ve kontrol grubu arasında istatistiksel olarak belirgin bir farklıIık olup olmadığını değerlendirmek içinse Independent Samples t Testi ve Mann Whitney $U$-testi yapılmıştır. Gruplar arasındaki korelasyonlar spearman korelasyon analizi ile değerlendirilmiştir. Parametrik ve non-parametrik değişkenlerin istatistiksel sonuçları sırasıyla ortalama \pm standart sapma ve ortanca (minimum-maksimum) olarak ifade edilmiştir. Çalışılan parametrelerin hastalığı ön görme gücü, Receiver operating characteristic (ROC) eğrisi kullanılarak 
eğri altında kalan alandan (AUC) hareketle tespit edilmiştir. İstatistiksel analizler 'Statistical Packages for the Social Sciences' (SPSS) versiyon 21.0 paket programı kullanılarak yapılmış ve $p<0.05$ düzeyi istatistiksel olarak belirgin farklıık düzeyi olarak kabul edilmiştir.

\section{Bulgular}

Çalışmaya 35 Behçet hastası, 35 sağlıklı kontrol dahil edilmiştir. Grupların yaş ortalaması sırasıyla $44.68 \pm 3.19$ ve $44.51 \pm 2.24$ olup, yaş ortalamaları arasında istatistiksel olarak belirgin bir farklılık yoktur $(p=0.940)$. Hastalara ait demografik veriler ve laboratuvar dataları Tablo 1'de özetlenmiştir.

Tablo 1. Hastalara ait demografik veriler ve laboratuvar bulguları.

\begin{tabular}{|c|c|c|c|}
\hline & $\begin{array}{l}\text { Behçet } \\
\text { grubu(n=35) }\end{array}$ & $\begin{array}{l}\text { Kontrol } \\
\text { grubu(n=35) }\end{array}$ & $\begin{array}{l}p \\
\text { değeri }\end{array}$ \\
\hline Yaş & $44.68 \pm 3.19$ & $44.51 \pm 2.24$ & 0.940 \\
\hline Cinsiyet(E/K) & $18 / 17$ & $17 / 18$ & 0.685 \\
\hline WBC (109/L) & $7.67 \pm 2.12$ & $7.52 \pm 1.96$ & 0.770 \\
\hline HGB (g/L) & $\begin{array}{l}14.0(1.2-17.0) \\
0.424(0.0403-\end{array}$ & $\begin{array}{l}14.1(9-16.9) \\
0.420(0.290-\end{array}$ & 0.837 \\
\hline $\mathrm{HCT}(\mathrm{L} / \mathrm{L})$ & $0.532)$ & $0.490)$ & 0.378 \\
\hline PLT (109/L) & $291.26 \pm 48.71$ & $260.14 \pm 59.00$ & 0.019 \\
\hline RBC (1012/L) & $4.92 \pm 0.56$ & $4.79 \pm 0.48$ & 0.313 \\
\hline $\mathrm{MCV}(\mathrm{fL})$ & $86.99 \pm 6.96$ & $86.62 \pm 4.17$ & 0.787 \\
\hline MCH (fmol) & $1.79(1.36-2.13)$ & $1.80(1.50-2.48)$ & 0.400 \\
\hline RDW (\%) & $15.0(11.4-19.5)$ & $14.0(12.0-18.0)$ & 0.021 \\
\hline PDW (\%) & $16.6(9.5-18.9)$ & $16.5(13.5-18.0)$ & 0.536 \\
\hline MPV (fL) & 8.1(6.9-11.0) & $8.3(6.7-15.0)$ & 0.254 \\
\hline NEU (109/L) & $4.9(3.2-9.5)$ & $4.0(1.3-8.0)$ & 0.007 \\
\hline $\begin{array}{l}\mathrm{LYM}\left(10^{9} / \mathrm{L}\right) \\
\text { MCHC(mmol/ } \\
\text { L) }\end{array}$ & 20.48(19.11-21.72) & $\begin{array}{l}2.23 \pm 0.80 \\
20.79(19.42- \\
21.78)\end{array}$ & 0.707 \\
\hline $\mathrm{ESR}(\mathrm{mm} / \mathrm{hr})$ & $14.0(2.0-47.0)$ & $10.0(2.0-29.0)$ & 0.047 \\
\hline $\begin{array}{l}\text { ALT (U/L) } \\
\text { CREA } \\
\text { (mmol/L) }\end{array}$ & $19.0(7.0-81.0)$ & $17.0(8.0-48.0)$ & 0.597 \\
\hline$M G(n g / m L)$ & $28.01(7.17-55.65)$ & $18.40(7.24-38.58)$ & $<0.001$ \\
\hline SPA (U/L) & $1015.07 \pm 165.5$ & $926.93 \pm 152.3$ & 0.024 \\
\hline IMA (ABSU) & $0.63 \pm 0.11$ & $0.51 \pm 0.15$ & $<0.001$ \\
\hline NLO & $2.43(1,33-5,94)$ & $2.0(0.54-5.17)$ & 0.011 \\
\hline PLO & $157.19 \pm 57.58$ & $125.30 \pm 48.43$ & 0.015 \\
\hline
\end{tabular}

ALT: alanin aminotransferaz, ESR: eritrosit sedimentasyon hIzı, CREA: kreatinin, HGB: hemoglobin, HCT: hematokrit, IMA: iskemi modifiye albümin, LYM: lenfosit, MG: metilglioksal, $M C H$ : ortalama korpusküler hemoglobin, MCHC: ortalama eritrosit hemoglobin konsantrasyonu, MCV: ortalama eritrosit hacmi, MPV: ortalama platelet hacmi, NEU: nötrofil, NLO: nötrofil lenfosit oranı, PDW: trombosit dağılım genişliği, PLT: platelet, PLO: platelet lenfosit oranı, RBC: kırmızı kan hücre sayISI, RDW: eritrosit dağılım genişliği, WBC: beyaz küre sayısı, SPA: serum prolidaz aktivitesi.

Behçet grubunda IMA ( $p<0.001)$, prolidaz, MG $(p<0.001)$, NLO ( $p=0.011)$, PLO (0.015), ESR $(p=0.047)$, RDW $(p=0.021), N E U(p=0.007)$ düzeyleri kontrol grubuna göre istatistiksel olarak belirgin düzeyde yüksek bulunurken $\mathrm{MCHC}$ değeri ise kontrol grubuna göre istatistiksel olarak belirgin düzeyde düşük bulunmuştur $(p=0.010)$. Özellikle temel araştırma konumuz olan IMA, MG ve SPA'nın hasta ve kontrol grubu arasındaki kıyaslaması Şekil 1'de özetlenmiştir.
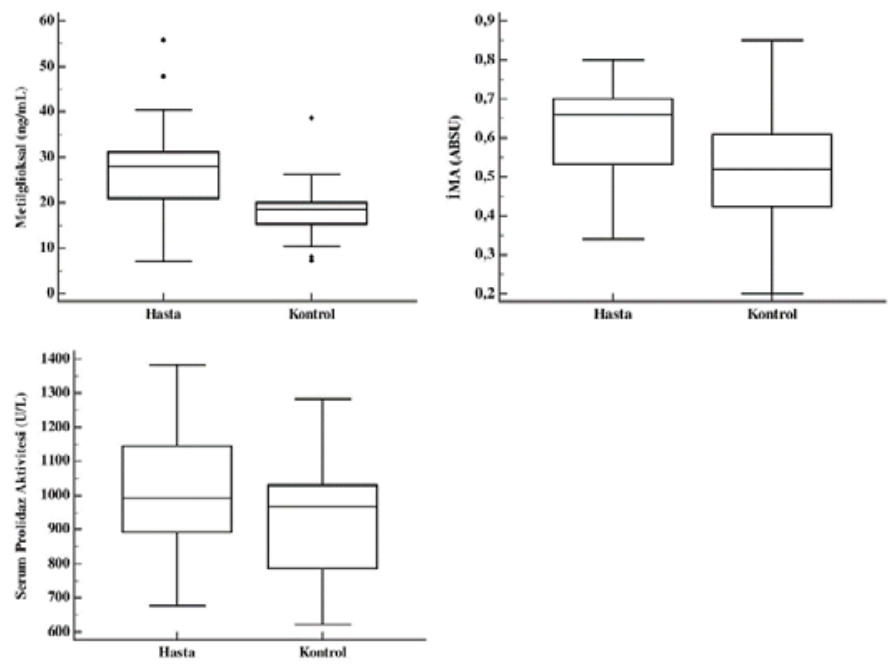

Şekil 1. Behçet ve kontrol grubunda serum MG, IMA düzeyleri ve SPA'nın karşıllaştıııması ABSU: absorbans ünitesi, MG: metilglioksal, SPA: serum prolidaz aktivitesi.

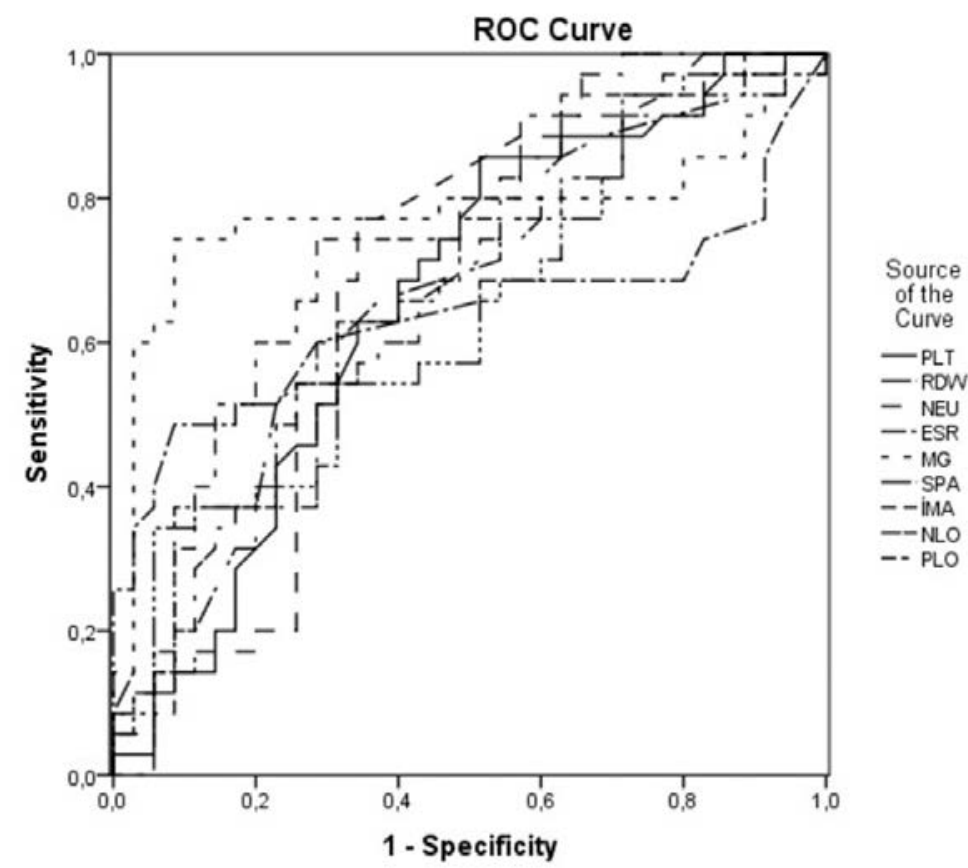

Şekil 2. ESR, PLT, RDW, NEU, MG, SPA, IMA, NLO ve PLO düzeylerine ait ROC eğrisi.

ESR: eritrosit sedimentasyon hIzı, IMA: iskemi modifiye albumin, MG: metilglioksal, NEU: nötrofil, NLO: nötrofil lenfosit oranı, PLO: platelet lenfosit oranı, PLT: platelet, RDW: eritrosit dağılım genişliği, SPA: serum prolidaz aktivitesi.

Spearman korelasyon analizine göre ise tüm gruplar (hasta ve kontrol) için değerlendirme yapıldı̆̆ında, SPA ile ESR $(r=0.261, p=0.029)$, kreatinin $(r=0.261, p=0.029)$ ve IMA $(r=0.350, p=0.003)$ düzeyleri arasında, IMA ile SPA'ya 
ek olarak NLO ( $r=0.241, p=0.045)$ düzeyleri arasında pozitif korelasyon bulunmuştur. Lineer regresyon analizi ile tüm gruplar için (hasta ve kontrol) değerlendirme yapıldığında ise IMA ile NLO ( $p=0.018, \beta=0.282)$ ve prolidaz ( $p=0.004$, $\beta=0.337$ ) arasında, prolidaz ile IMA'ya ek olarak kreatinin düzeyleri arasında ( $p=0.018, \beta=0.283)$ doğrusal bir ilişki bulunmuştur.

Behçet hastalığını öngörme gücünü değerlendirmek amacıyla yapılan ROC analizinde, MG, SPA, IMA, PLT, RDW, NEU, MCHC, ESR, NLO'ya ait veriler Tablo 2'de özetlenmiştir. ROC analiz eğrisi ise Şekil 2'de gösterilmiştir.

Tablo 2. ESR, PLT, RDW, NEU, MG, SPA, IMA, NLO ve PLO 'nun Behçet hastalı̆ııı öngörme gücüne ait Cut-Off, Sensitivite, Spesifisite, AUC, \%95 güven aralığı ve $p$ değerleri.

\begin{tabular}{|c|c|c|c|c|c|c|}
\hline & Cut-off & $\begin{array}{l}\text { Sensitivite } \\
\text { (\%) }\end{array}$ & $\begin{array}{l}\text { Spesifite } \\
\text { (\%) }\end{array}$ & AUC & $\% 95 \mathrm{Cl}$ & $\mathbf{P}$ \\
\hline ESR (mm/h) & 15.3 & 49 & 91 & 0.638 & $\begin{array}{l}0.499- \\
0.777 \\
0.531-\end{array}$ & $\begin{array}{l}0.04 \\
7 \\
0.02\end{array}$ \\
\hline PLT $(103 / \mu L)$ & 245.5 & 86 & 49 & 0.660 & $\begin{array}{l}0.531- \\
0.790 \\
0.532-\end{array}$ & $\begin{array}{l}0.02 \\
1 \\
0.02\end{array}$ \\
\hline RDW (\%) & 14.85 & 51 & 77 & 0.660 & $\begin{array}{l}0.789 \\
0.557-\end{array}$ & $\begin{array}{l}1 \\
0.00\end{array}$ \\
\hline NEU (109/L) & 4.22 & 77 & 66 & 0.686 & $\begin{array}{l}0.816 \\
0.657-\end{array}$ & $\begin{array}{l}7 \\
0.00\end{array}$ \\
\hline MG (ng/mL) & 22.03 & 74 & 91 & 0.780 & $\begin{array}{l}0.902 \\
0.507-\end{array}$ & $\begin{array}{l}0 \\
0.04\end{array}$ \\
\hline SPA (U/L) & 1071.02 & 37 & 89 & 0.637 & $\begin{array}{l}0.767 \\
0.612-\end{array}$ & $\begin{array}{l}9 \\
0.00\end{array}$ \\
\hline IMA (ABSU) & 0.565 & 74 & 71 & 0.732 & $\begin{array}{l}0.853 \\
0.551-\end{array}$ & $\begin{array}{l}1 \\
0.01\end{array}$ \\
\hline NLO & 1.72 & 83 & 46 & 0.676 & $\begin{array}{l}0.802 \\
0.546-\end{array}$ & $\begin{array}{l}1 \\
0.01\end{array}$ \\
\hline PLO & 146.31 & 60 & 71 & 0.673 & 0.799 & 3 \\
\hline
\end{tabular}

AUC: eğri altında kalan alan, Cl: güven aralığı, ESR: eritrosit sedimentasyon hızı, IMA: iskemi modifiye albumin, MG: metilglioksal, NEU: nötrofil, NLO: nötrofil lenfosit oranı, PLO: platelet lenfosit oranı, PLT: platelet, RDW: eritrosit dağııım genişliği, SPA: serum prolidaz aktivitesi.

\section{Tartışma}

Behçet hastalığı tekrarlayan oral aft, genital ülser, cilt lezyonları, üveit ile karakterize olan, kronik, otoimmün, enflamatuvar, multisistemik tutulum gösteren bir hastalıktır. Behçet hastalığının klinik bulgularının çoğunun vaskülitten kaynaklandığı belirtilmiş olup, Behçet hastalığında vasküler tululum en önemli morbidite ve mortalite nedenlerinden birisidir (24). Behçet hastalı̆ında görülen vasküler patolojinin altında yatan mekanizmalar henüz tam olarak aydınlatılamamıştır. Son çalışmalardan elde edilen kanıtlar, aktive olmuş lökositlerin hastalıktaki vasküler hasara katkıda bulunabileceğini göstermektedir. Behçet hastalarında işlevi bozulan nötrofiller, aşırı miktarda reaktif oksijen türevlerinin üretimine yol açarak in-vitro endotel hücre lizisine neden olmaktadır. Hastalıkta dolaşımdaki pro-oksidanların ve lipit peroksidasyon ürün konsantrasyonlarının yükseldiği bildirilmiş olmakla birlikte oksidatif stres ile vasküler komplikasyon arasındaki ilişki henüz tam olarak aydınlatılamamıştır (9).

Behçet hastalığında spesifik bir laboratuvar bulgusu yoktur. İnanır ve ark. tarafından 66 Behçet hastası, 22 kontrol üzerinde yapılan çalışmada ESR $(27.9 \pm 7.1$ ve $9.4 \pm 5.6$ $\mathrm{mm} / \mathrm{h}$, sirasiyla) ve CRP ( $8.4 \pm 2.8$ ve $3.6 \pm 1.8 \mathrm{mg} / \mathrm{L}$, sırasıyla ) düzeylerinin hasta grubunda kontrol grubuna göre istatistiksel olarak belirgin düzeyde $(p<0.05)$ yüksek olduğu saptanmıştır (25). Aksoy ve ark. tarafından yapılan çalışmaya 236 Behçet hastası, 72 kontrol dahil edilmiş ve tüm bireylerde hsCRP, ESR, RDW düzeyleri ölçülmüştür. ÇaIIşma sonucunda her 3 parametrede hasta grubunda kontrol grubuna göre yüksek bulunmuştur (26). Behçet hastalığında ESR, CRP gibi çeşitli rutin parametrelerin düzeylerinin yüksek olduğu gösterilmiştir, bununla birlikte bu parametrelerin düzeylerindeki değişim klinik aktiviteyle her zaman paralellik göstermemektedir. Dolayısıyla Behçet hastalığının tanısında klinik aktiviteyle uyumlu laboratuvar belirteçlerine gereksinim duyulmaktadır.

IMA iskemi ve oksidatif stres için oldukça spesifik ve sensitif bir biyobelirteç olarak kabul edilmektedir. Pek çok iskemik hastalıkta geniş ölçüde çalışılmıştır. Ek olarak, vasküler endotelyal hücre fonksiyon bozukluğunun eşlik ettiği hastalıklarda IMA düzeylerinin yükseldiği bulunmuştur. Capkin ve ark. tarafından 35 Behçet hastası, 31 kontrol üzerinde yapılan çalışmalarda IMA düzeylerinin Behçet grubunda ( $0.63 \pm 0.25 \mathrm{ABSU})$ kontrol grubuna $(0.42 \pm 0.12$ ABSU) göre istatistiksel olarak belirgin düzeyde $(p=0.0001)$ yüksek olduğu bildirilmiştir (27). Kilıç ve ark. tarafından 26 Behçet hastası, 28 kontrol üzerinde yapılan çaIışmada ise aktif Behçet hastalarında (0.93 $\pm 0.13 \mathrm{ABSU})$ iMA düzeyleri inaktif dönemdeki hastalara $(0.82 \pm 0.14$ $A B S U)$ ve kontrol grubuna $(0.83 \pm 0.07 \mathrm{ABSU})$ göre istatistiksel olarak belirgin düzeyde $(p=0.041)$ yüksek bulunmuştur (28). Keskin ve ark. tarafından 57 Behçet hastası, 45 sağlıklı kontrol üzerinde yapılan çalışmada ise her iki grupta IMA, total antioksidan seviyeleri (TAS), total oksidan seviyeleri (TOS), oksidatif stres indeksi (OSI), C-reaktif protein, ESR düzeyleri ölçülmüş olup tüm parametrelerin düzeyi Behçet grubunda kontrol grubuna göre yüksek bulunurken, yalnızca IMA'nın hastalığın aktif ve inaktif dönemi için ayırt edici bir markır olduğu ve ROC analizinde AUC değerinin diğer markırlara göre yüksek olduğu $(p=0.004)$ saptanmıştır (29). Bizim çalışmamızda da benzer şekilde IMA düzeyleri hasta grubunda $(0.63 \pm 0.11$ ABSU) kontrol grubuna (0.51 $\pm 0.15 \mathrm{ABSU})$ göre istatistiksel olarak belirgin düzeyde $(p<0.001)$ yüksek bulunmuştur. Prolidaz hem insan hem de hayvan dokularında ekspresse edilen ve kollajen metabolizmasında rol oynayan bir enzim olup SPA'daki değişiklikler oksidatif stres ve fibrozis ile karakterize olan hastalıklarla ilişkilidir. Yapılan çalışmalar, büyüme faktörlerinin ve transkripsiyon faktörlerinin düzenlenmesi yoluyla prolidazın, yara iyileşmesi, iltihaplanma ve anjiyogenez dahil olmak üzere birçok fizyolojik ve patolojik süreçte önemli rol oynayabileceğini vurgulamaktadır. Bozkurt ve ark. tarafından 42 Behçet hastası (18 aktif, 24 inaktif), 29 kontrol üzerinde yapılan çalışmada SPA aktif hasta 
grubunda inaktif gruba ve kontrol grubuna göre yüksek bulunmuştur (15). Ayrıca serum prolidaz aktivitesi hasta grubunda (4.68 $0.59 \mathrm{U} / \mathrm{L})$ kontrol grubuna $(3.96 \pm 1.19 \mathrm{U} / \mathrm{L})$ göre de istatistiksel olarak belirgin düzeyde $(\mathrm{p}=0.013)$ yüksek bulunmuştur. Bizde çalışmamızda benzer şekilde hasta grubunda (1015.07 $\pm 165.5 \mathrm{U} / \mathrm{L})$ kontrol grubuna $(926.93 \pm 152.3 \mathrm{U} / \mathrm{L})$ göre serum prolidaz aktivitesini istatistiksel olarak belirgin düzeyde $(p=0.024)$ yüksek bulduk. Glikolitik yolağın yan ürünü olarak üretilen $M G$, reaktif karbonil türevlerinden birisidir ve AGEs üretimi için güçlü bir prekürsördür. MG özellikle proteinler üzerindeki arjinin kaIıntıları ile reaksiyona girmekte, proteinlerde glikasyona, çapraz bağlanmalara, yapısal değişikliklere, hücresel hasara yol açarak birçok hastalığın patogenezinde rol oynamaktadır. Çeşitli çalışmalarla, sadece hiperglisemide değil, aynı zamanda enflamatuar hastalıklarda, hipoksi, yaşlanma, aterosklerozda da artmış MG düzeyleri bildirilmiştir (14). Behçet hastalarında MG düzeylerine ilişkin bir çalışma mevcut değildir. Ancak çeşitli enflamatuvar hastalıklarda MG düzeylerinin yükseldiği bildirilmiştir. Knani ve ark. tarafından 80 romatoid artrit hastası, 30 kontrol üzerinde yapılan çalışmada serum MG düzeyleri hasta grubunda $(137.6 \pm 76.6 \mathrm{ng} / \mathrm{mL})$ kontrol grubuna $(80.4 \pm 25.2 \mathrm{ng} / \mathrm{mL})$ göre istatistiksel olarak belirgin düzeyde yüksek bulunmuştur $(p<0.001)(30)$. Ayrıca son zamanlarda, MG'nin vasküler patolojilerde de rol oynayabileceği gösterilmiştir. İlerleyen yıllarda MG, MG türevi AGE'ler ve glioksalaz sisteminin, diyabetik ve diyabetik olmayan kişilerde vasküler komplikasyonlara ilişkin risk tahmini ve erken tanıda kullanılabileceği düşünülmektedir. Behçet hastalığında da yaygın görülen endotel disfonksiyon göz önüne alınırsa MG'in Behçet hastalığındaki vasküler tutulumlar için bir gösterge olabileceği de düşünülebilir. Behçet hastalarında MG düzeylerinin ölçümüne yönelik ilk çalışma olan çalışmamızda, MG düzeylerini Behçet grubunda (28.01(7.17-55.65) $\mathrm{ng} / \mathrm{mL}$ ) kontrol grubuna (18.40(7.24-38.58) $\mathrm{ng} / \mathrm{mL}$ ) göre istatistiksel olarak belirgin düzeyde $(p<0.001)$ yüksek bulduk.

Behçet hastalığında spesifik bir laboratuvar bulgusunun olmaması hastalığın tanısında tutarsızıklara yol açmaktadır. Behçet hastalarında ESR, CRP, RDW gibi parametrelerin yükseldiği gösterilse de bu parametreler hastalığa spesifik değildir. Dolayısıyla hastalığın tanısında daha özgül belirteçlere gereksinim vardır. Yaptığımız çalışmadan elde ettiğimiz sonuçlara göre IMA, SPA ve MG'in hastalık için potansiyel birer laboratuvar göstergesi olabileceğini düşünmekteyiz. Bununla birlikte çalışmamızın en önemli tarafı Behçet hastalarında MG düzeylerine yönelik ilk çalışma olmasıyken, en önemli dezavantajı çalışmaya dahil edilen hasta sayısının az olmasıdır.

\section{Açıklamalar \\ Etik onam: Bu çalışma Selçuk Üniversitesi Tıp Fakültesi Yerel Etik Kurul Başkanlığının 18/09/2019 tarih ve}

2019/217 sayılı etik kurul kararıyla onaylanmıştır.

\section{Kaynaklar}

1. Ferizi M, Gerqari A, Ferizi M. Behçet's disease - case presentation and review literature. Open Access Maced J Med Sci. 2018; 6(10):18714.

2. Scherrer MAR, Rocha VB, Garcia LC. Behçet's disease: review with emphasis on dermatological aspects. An Bras Dermatol. 2017; 92(4):452-64.

3. Nair JR, Moots RJ. Behcet's disease. Clin Med (Lond). 2017; 17(1):71-7.

4. Melikoğlu MA, Melikoğlu M. The influence of age on Behcet's disease activity. Eurasian J Med. 2008; 40(2):68-71.

5. Kokturk A. Clinical and pathological manifestations with differential diagnosis in Behçet's disease. Patholog Res Int. 2012; 2012:690390.

6. Moses PD, George R. Ocular manifestations of Behcet's disease. Indian Pediatr. 2005; 42(9):942-5.

7. Ceylan N, Bayraktaroglu S, Erturk SM, Savas R, Alper H. Pulmonary and vascular manifestations of Behcet disease: imaging findings. AJR Am J Roentgenol. 2010; 194(2):158-64.

8. Chen Y, Cai JF, Lin CH, Guan JL. Demography of vascular Behcet's disease with different gender and age: an investigation with 166 Chinese patients. Orphanet J Rare Dis. 2019; 14(1):88.

9. Fouad N, Ahmed T, Shaker O, Abdelaleem O. Relation of ischemiamodified albumin to disease manifestations and activity in Egyptian patients with Behcet's disease. Egypt Rheumatol. 2019; 46(2):108-12.

10. Majtan J. Methylglyoxal-a potential risk factor of manuka honey in healing of diabetic ulcers. Evid-Based Compl Alt. 2011; 2011:295494.

11. Allaman I, Bélanger M, Magistretti PJ. Methylglyoxal, the dark side of glycolysis. Front in Neurosci. 2015; 9(23).

12. Yadav SK, Singla-Pareek SL, Sopory SK. An overview on the role of methylglyoxal and glyoxalases in plants. Drug Metabol Drug Interact. 2008; 23(1-2):51-68.

13. Wetzels $S$, Wouters $K$, Schalkwijk CG, Vanmierlo T, Hendriks JJA. Methylglyoxal-derived advanced glycation endproducts in Multiple Sclerosis. Int J Mol Sci. 2017; 18(2):421.

14. Schalkwijk CG. Vascular AGE-ing by methylglyoxal: the past, the present and the future. Diabetologia. 2015; 58(8):1715-9.

15. Bozkurt M, Yüksel H, Em S, Oktayoglu P, Yildiz M, Akdeniz D, et all. Serum prolidase enzyme activity and oxidative status in patients with Behçet's disease. Redox Rep. 2014; 19(2):59-64.

16. Collinson PO, Gaze DC. Ischaemia-modified albumin: clinical utility and pitfalls in measurement. J Clin Pathol. 2008; 61(9):1025-8.

17. Leitemperguer MR, Tatsch E, Kober H, Carvalho JA, Moresco RN, Silva JE. Assessment of ischemia-modified albumin levels in patients with rheumatoid arthritis. Clin Lab. 2014; 60(6):1065-70.

18. Ozdemir M, Kiyici A, Balevi A. Assessment of ischaemia-modified albumin level in patients with psoriasis. Clin Exp Dermatol. 2012; 37:610-4.

19. Guntas G, Sahin A, Duran S, Kahraman R, Duran I, Sonmez C, et all. Evaluation of ischemia-modified albumin in patients with inflammatory bowel disease. Clin Lab. 2017; 63(2):341-7.

20. Bonorino NF, Lunardelli A, Oliveira JR. Use of ischemia modified albumin for the diagnosis of myocardial infarction. J Bras Patol Med Lab. 2015; 51(6):383-8.

21. Wang X, Desai K, Clausen JT, Wu L. Increased methylglyoxal and advanced glycation end products in kidney from spontaneously hypertensive rats. Kidney Int. 2004; 66(6):2315-21.

22. Myara I, Myara A, Mangeot M, Fabre M, Charpentier $C$, Lemonnier A. Plasma prolidase activity: a possible index of collagen catabolism in chronic liver disease. Clin Chem. 1984; 30(2):211-5.

23. Bar-Or D, Lau E, Winkler JV. A novel assay for cobalt-albumin binding and its potential as a marker for myocardial ischemia-a preliminary report. J Emerg Med. 2000; 19(4):311-5.

24. Zeidan MJ, Saadoun D, Garrido M, Klatzmann D, Six A, Cacoub P. Behçet's disease physiopathology: a contemporary review. Auto Immun 
Highlights. 2016; 7(1):4.

25. İnanır I, Onur E, Pırıldar T, Gündüz K, Var A. IL-2R, IL-6 and IL-8 levels in Behçet's disease. Türkdem. 2010; 44: 213-5.

26. Aksoy SN, Savas E, Sucu M, Kisacik B, Kul S, Zengin O. Association between red blood cell distribution width and disease activity in patients with Behcet's disease. J Int Med Res. 2015; 43(6):765-73.

27. Capkin E, Karkucak M, Kola M, Karaca A, Aydin Capkin A, Caner $\mathrm{KS}$. Ischemia-modified albumin (IMA): a novel marker of vascular involvement in Behcet's disease? Joint Bone Spine. 2015; 82(1):68-9.

28. Kılıç S, Işık S, Hiz MM, Çakır DÜ, Türkön H, Cevizci S, et all. The ischemia modified albumin and mean platelet volume levels in patients with Behçet's disease. Postepy Dermatol Alergol. 2016; 33(5):345-8.

29. Keskin S, Arica DA, Orem A, Akçan B, Menteşe A, Bahadır S. Ischemia modified albumin: a useful marker for increased oxidative stress in Behçet's disease. Mucosa. 2019; 2(1):19-27.

30. Knani I, Bouzidi H, Zrour S, Bergaoui N, Hammami M, Kerkeni M. Methylglyoxal: A relevant marker of disease activity in patients with rheumatoid arthritis. Dis Markers. 2018; 2018:6. 